\title{
In vitro anti oxidant activity and total phenolic content of Dillenia indica and Garcinia penducalata, commonly used fruits in Assamese cuisine
}

\author{
Munmee Das, ${ }^{1}$ Bishnu P. Sarma, ${ }^{1}$ Giasuddin Ahmed, ${ }^{2}$ Cakkalur Balasubramaniam Nirmala, ${ }^{3}$ \\ Monjoy Kumar Choudhury ${ }^{3,4 *}$
}

${ }^{1}$ Govt. Ayurvedic College, Jalukbari, Guwahati. Assam. India

${ }^{2}$ Department of Biotechnology, Guwahati University. Assam, India

${ }^{3}$ Department of Biotechnology, SRM Arts and Science College, Kattankalathur, District Kanchipuram, Tamil Nadu, India

${ }^{4}$ Department of Biochemistry, University of Science and Technology, Meghalaya (USTM), Killing Road, Baridua, $9^{\text {th }}$ mile, G. S. Road, Ri-Bhoi, Meghalaya, India

Submission Date: 23-12-2011; Revised Date: 12-1-2012; Accepted Date: 31-1-2012

\begin{abstract}
Introduction: Ingredients of Indian cuisine are well known for their antioxidant properties which can help prevent many diseases. The fruits of Dillenia indica and Garcinia penducalata are commonly used by the Assamese speaking population of Assam, India, but their antioxidant properties have not been investigated. Methods: Methanol, petroleum ether and water extracts of the shade dried fruits of Dillenia indica and Garcinia penducalata were obtained and the $\mathrm{IC}_{50}$ values of their DPPH, hydroxyl, oxygen and nitric oxide scavenging activities were estimated along with their reductive ability, vitamin $\mathrm{C}$ and total phenolic content. Vitamin $\mathrm{C}$ was used as a standard reference for the antioxidant scavenging activities. Result: $\mathrm{The}_{\mathrm{IC}}$ values for $\mathrm{DPPH}$, hydroxyl, oxygen and nitric oxide inhibition of vitamin $\mathrm{C}$ were $43.7 \mathrm{ug} / \mathrm{ml}, 50.44 \mathrm{ug} / \mathrm{ml}, 61.04 \mathrm{ug} / \mathrm{ml}$ and $41.82 \mathrm{ug} / \mathrm{ml}$, respectively while the IC $_{50}$ value for its reductive ability was $47.17 \mathrm{ug} / \mathrm{ml}$. The $\mathrm{IC}_{50}$ values for the DPPH, hydroxyl, oxygen, nitric oxide and reductive ability of the methanolic extract of Dillenia indica were $31.25 \mathrm{ug} / \mathrm{ml}, 51.82 \mathrm{ug} / \mathrm{ml}, 51.44 \mathrm{ug} / \mathrm{ml}, 39.73 \mathrm{ug} / \mathrm{ml}$ and $40.18 \mathrm{ug} / \mathrm{ml}$, respectively. These $\mathrm{IC}_{50}$ values were superior in comparison to its petroleum ether and water extracts. The methanolic extract of Garcinia penducalata had the highest amount of phenolic content and its $\mathrm{IC}_{50}$ values for DPPH, oxygen and nitric oxide scavenging activities were $50.23 \mathrm{ug} / \mathrm{ml}, 66.06 \mathrm{ug} / \mathrm{ml}$ and $63.02 \mathrm{ug} / \mathrm{ml}$, respectively. Conclusion: The higher amount of phenolic content in the methanolic extract of Dillenia indica may contribute to its better in vitro anti oxidant property.
\end{abstract}

Keywords: antioxidant activity, Assam, Dillenia indica, Garcinia penducalata, total phenolic content.

${ }^{*}$ Corresponding address:

Monjoy Kumar Choudhury

Assistant Professor, Department of Biochemistry

University of Science and Technology, Meghalaya (USTM)

Killing Road, Baridua, $9^{\text {th }}$ mile, G. S. Road,

Ri-Bhoi, Meghalaya, India.

E mail: monjoy ch@yahoo.com

DOI: 10.5530/ax.2012.2.6

\section{INTRODUCTION}

Free radicals are paramagnetic molecular species which possess unpaired electron in its outer orbital..$^{[1]}$ The free radicals increase in the body when the body's antioxidant system weakens. An oxidative stress is caused when the free radicals exceed the homeostasis level, leading to diseases. ${ }^{[2-6]}$ Oxidative stress is initiated by reactive oxygen species (ROS) such as hydrogen peroxide and superoxide anions, that react 
Munmee Das, et al.: In vitro anti oxidant activity and total phenolic content

with the living tissues and cause harmful effects such as lipid peroxidation, DNA fragmentation and cross linking of proteins and enzymes in them thereby causing diseases. ${ }^{\left[{ }^{[7}\right.}$

Human diet can be a major source of antioxidants. Polyphenols which are organic compounds present in regular human diet have an antioxidant property. ${ }^{[8-10]}$ Early men lived in forests and his food habits provided him dietary antioxidants to cope up with ROS but after the initiation of organized farming his food habits changed and now the food habits are completely different with very little dietary derived antioxidants. Moreover human beings are constantly facing environmental toxins. This might be one of the major reasons for the increase in the metabolic disorders in the present population. ${ }^{[11,12]}$

Although a number of commercial antioxidants are available they may not be enough to cure diseases arising due to increase in free radicals or decrease in the efficacy of antioxidant system in our body. One of the major sources of free radicals is the mitochondria and the mitochondrial mutation can be the possible cause of many diseases. ${ }^{[13-15]}$

Most of the diseases are detected too late that cause irreversible damage to the body. Therefore food that forms the natural source of antioxidants, can prevent free radicals from damaging our body tissues. ${ }^{[16,17]}$

Dillenia indica and Garcinia penducalata are two major fruits, easily available in Assam, North eastern India and its decoction is a major part of Assamese cuisine. They are sour in taste and are rich in vitamin C. There are many components of Indian cuisine which provide protection against free radicals and also enhance our body's antioxidant system. ${ }^{[18,19]}$ In the present study, the in vitro antioxidant properties of the fruits of these plants are compared.

\section{MATERIALS AND METHODS}

\section{Plant material}

The fruits of G. penducalata and D. indica were collected in the month of June, 2011. The fruits were washed in distilled water. They were cut into small pieces and shade dried for a week. Later the dried fruits were mechanically grounded into a coarse powder. The samples of the same are deposited in the Centre for Biocultural Diversity (CBD), Chennai and the voucher receipt for the $G$. penducalata Roxb. and D. indica L. are MK1108201129 and MK1108201128, respectively.

\section{Chemicals}

All analytical grade chemicals used for the experiments were purchased from SRL, India Pvt. Ltd.

\section{Preparation of extract}

Soxlet extraction was done for 72 hours to prepare the methanol and petroleum extracts of the coarse fruit powders of the two plants. The emulsions obtained were powdered by using a rotary evaporator to obtain the dry extracts. A part of the coarse dry powder of the fruits was soaked in water overnight and the supernatants obtained were filtered and lyophilized. This lyophilized powders formed the water extracts of the plants. The methanolic and petroleum ether extracts and the lyophilized water extract were used for in vitro antioxidant analysis. The per cent concentrations of the methanolic, petroleum ether and water extracts of $G$. penducalata were $15 \%, 10 \%$ and $8 \%$ while they were $4 \%, 2 \%$ and $6 \%$, respectively for $D$. indica.

\section{DPPH RADICAL SCAVENGING ACTIVITY}

DPPH free radical scavenging activity of the methanol, petroleum ether and water extracts of G. penducalata and D. indica fruits were carried out by the methods of Cotelle A et al. (1996). ${ }^{[2]}$ Different concentrations ranging from $10-110 \mathrm{ug} / \mathrm{ml}$ of the extracts were added to $100 \mathrm{uM}$ of DPPH (2,2, Diphenyl-2-picryl hydrazyl) and the absorbance was read at $517 \mathrm{~nm}$ after incubation. Ascorbic acid was used as the standard.

\section{NITRIC OXIDE RADICAL SCAVENGING ACTIVITY}

Different concentrations of the methanol, petroleum ether and water extracts of $G$. penducalata and $D$. indica fruits were

Table 1 Levels of phenolic content and ascorbic acid in the extracts of $D$. Indica and G. penducalata

\begin{tabular}{lcccc}
\hline & \multicolumn{3}{c}{ Extracts } \\
\cline { 2 - 4 } & Methanol & Petroleum ether & Water \\
\hline Phenolic content & & D. indica & $3 \%$ & $0.8 \%$ \\
Ascorbic acid & $8 \%$ & & $0.5 \%$ & $8 \%$ \\
Phenolic content & $3 \%$ & G. penduculata & & $0.6 \%$ \\
Ascorbic acid & $5 \%$ & & $0.2 \%$ & $6 \%$ \\
\hline
\end{tabular}


Munmee Das, et al.: In vitro anti oxidant activity and total phenolic content

mixed with sodium nitroprusside and incubated. Griess reagent was added to the mixtures and their optical density was read at $546 \mathrm{~nm}$ following the method of Marcocci et al. (1994). ${ }^{[21]}$ Ascorbic acid was used as the standard.

\section{HYDROXYL RADICAL SCAVENGING ACTIVITY}

In order to find the scavenging activity of the extracts against hydroxyl radicals, the method of Kunchandy \& Ohkawa (1990) ${ }^{[22]}$ was followed. The reaction mixture consisted of $28 \mathrm{mM}$ 2-deoxy-D-ribose, $1.04 \mathrm{mM}$ EDTA, $0.2 \mathrm{mM} \mathrm{FeCl}_{3}, 1.0 \mathrm{mM}$ hydrogen peroxide along with different concentrations of the methanol, petroleum ether and water extracts of $G$. penducalata and $D$. indica fruits. Ascorbic acid was used as a standard drug. After $60 \mathrm{~min}$ of incubation, DNA damage was assessed by the method of Ohkawa et al. (1979).[23]

\section{SUPEROXIDE RADICAL SCAVENGING ACTIVITY}

The superoxide scavenging activity of the methanol, petroleum ether and water extracts of the fruits was determined by the method of Robak \& Gryglewski (1998).[24] Different concentrations of the extracts were mixed with $156 \mathrm{uM}$ nitro blue tetrazolium (NBT), $468 \mathrm{uM}$ reduced nicotinamide adenine dinucleotide (NADH) and $60 \mathrm{uM}$ phenazine methosulphate (PMS). After incubation, the optical density of the reaction mixtures was measured at $560 \mathrm{~nm}$ and the percentage inhibition calculated.

\section{DETERMINATION OF REDUCING ABILITY}

The reducing ability of methanol, petroleum ether and water extracts of the fruits was analyzed using the method of Jayprakash et al. (2001). ${ }^{[25]}$ The extracts in different concentrations were mixed with $1 \%$ potassium ferricyanide and incubated. The reactions were stopped using 10\% TCA and the reaction mixtures were centrifuged. Equal volumes of water and $0.1 \%$ ferric chloride were added to the supernatants. Absorbance was measured at $700 \mathrm{~nm}$.

\section{DETERMINATION OF TOTAL PHENOLIC COMPOUNDS}

The total phenolic content was analyzed by the method of Slinkard \& Singleton (1977). ${ }^{[26]}$ An aliquot of $1.5 \mathrm{ml}$ of $2 \mathrm{~N}$ Folin-Ciocalteau was added to different concentrations gallic acid and incubated at room temperature. Sodium carbonate ( $20 \%$ aqueous) solution was added and the volume of all the mixtures was made up to $10 \mathrm{~mL}$ using distlled water. After incubation for 30 minutes, the absorbance was read at $760 \mathrm{~nm}$. Known standard extracts $(0.1 \mathrm{~mL})$ from the fruits of $G$. penducalata and D. indica were processed in the same way.

\section{DETERMINATION OF ASCORBIC ACID}

The method for the estimation of total ascorbic acid in the extracts was done according to Indian Pharmacopia (1996). ${ }^{[27]}$

Solution containing $0.2 \mathrm{mg}$ ascorbic acid/ $\mathrm{ml}$ was prepared in water containing 3\% w/v metaphosphoric acid. It was titrated against $0.5 \mathrm{mg} / \mathrm{ml}$ of 2,6-dichlorophenol indophenol (2,6-DCPIP) solution. End point was the development of permanent pink coloration. Sample solutions containing known quantities of the extracts of $G$. penducalata and $D$. indica were mixed and titrated to determine the amounts of ascorbic acid present in different extracts.

Per cent inhibition was calculated by using the formula,

$$
\text { Per cent inhibition }=\frac{A_{\text {control }}-A_{\text {test }}}{A_{\text {control }}} \times 100
$$

$A_{\text {control }}$ : Absorbance of the control sample.

$A_{\text {test }}:$ Absorbance of the test sample.

\section{STATISTICAL ANALYSIS}

Six replicates were maintained in each of the experiments and their SEM was evaluated based on which, non linear regression (curve fit), exponential growth were derived to calculate the $\mathrm{IC}_{50}$ values of the SAWE and standard compounds. All the statistical analyses were done by using paired $t$ test.

\section{RESULTS}

\section{DPPH inhibition}

As shown in Figure $1 \mathrm{a}$, the $\mathrm{IC}_{50}$ values for $\mathrm{DPPH}$ inhibition of vit $\mathrm{C}$, methanol, petroleum ether and water extracts of $D$. indica were $43.7 \mathrm{ug} / \mathrm{ml}, 31.25 \mathrm{ug} /$ $\mathrm{ml}, 65.77 \mathrm{ug} / \mathrm{ml}$ and $74.73 \mathrm{ug} / \mathrm{ml}$ and the values for G. penduculata (Figure 1b) were $43.7 \mathrm{ug} / \mathrm{ml}, 50.23 \mathrm{ug} /$ $\mathrm{ml}, 75.69 \mathrm{ug} / \mathrm{ml}$ and $106.95 \mathrm{ug} / \mathrm{ml}$, respectively.

\section{Hydroxyl radical}

The $\mathrm{IC}_{50}$ values for hydroxyl radicals of vit $\mathrm{C}$, methanol, petroleum ether and water extracts of $D$. indica 


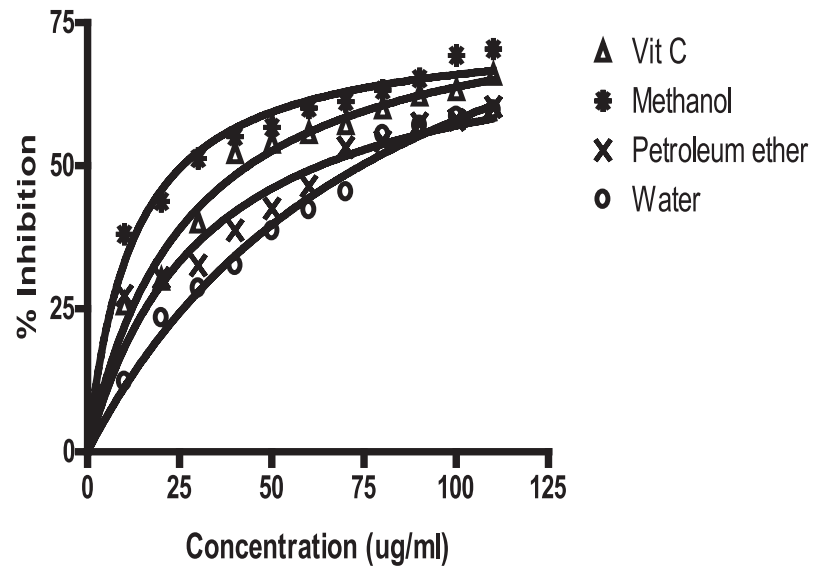

Figure 1a. DPPH Inhibitory activity of D. indica.

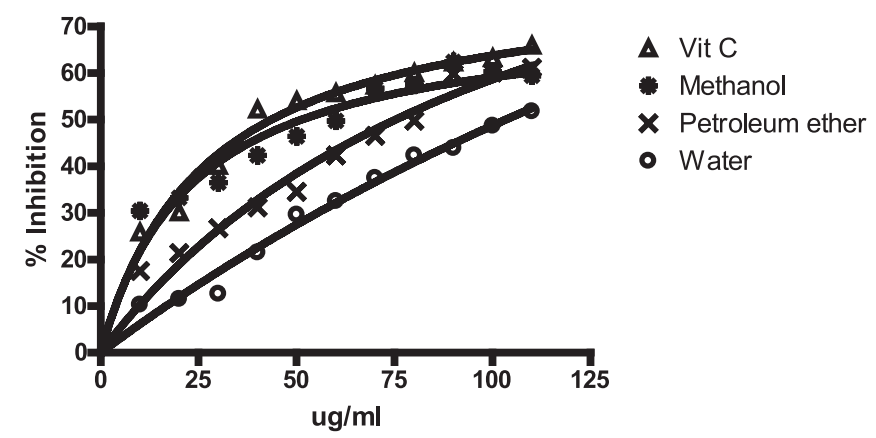

Figure 1b. DPPH Inhibitory activity of G. penducalata.

were $50.44 \mathrm{ug} / \mathrm{ml}, 51.82 \mathrm{ug} / \mathrm{ml}, 58.12 \mathrm{ug} / \mathrm{ml}$ and $75.1 \mathrm{ug} / \mathrm{ml}$, respectively (Figure $2 \mathrm{a}$ ). The $\mathrm{IC}_{50}$ values of the extracts of $G$. penducalata were $>110 \mathrm{ug} / \mathrm{ml} \mathrm{con-}$ centration (Figure 2b).

\section{Oxygen radical}

The $\mathrm{IC}_{50}$ values for oxygen radical scavenging activity of vit $\mathrm{C}$, methanolic, petroleum and water extracts of D. indica were $61.04 \mathrm{ug} / \mathrm{ml}, 51.44 \mathrm{ug} / \mathrm{ml}, 78.42 \mathrm{ug} / \mathrm{ml}$ and $92.44 \mathrm{ug} / \mathrm{ml}$, respectively (Figure $3 \mathrm{a}$ ). The $\mathrm{IC}_{50}$ value

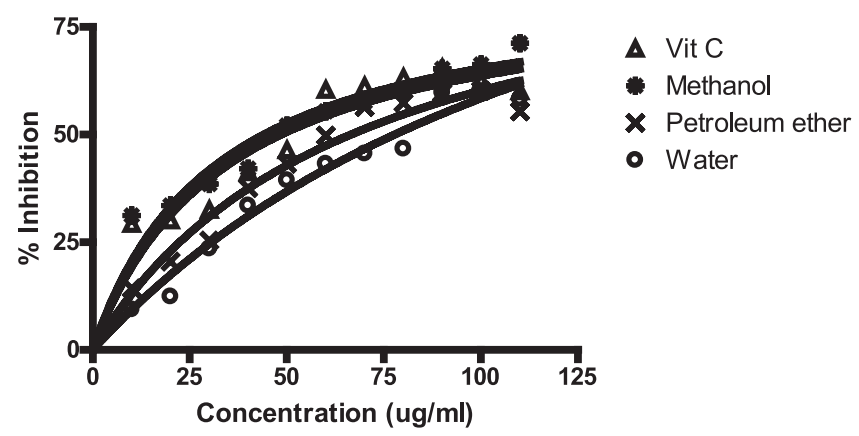

Figure 2a. Inhibition of Hydroxyl radical by $D$. indica.

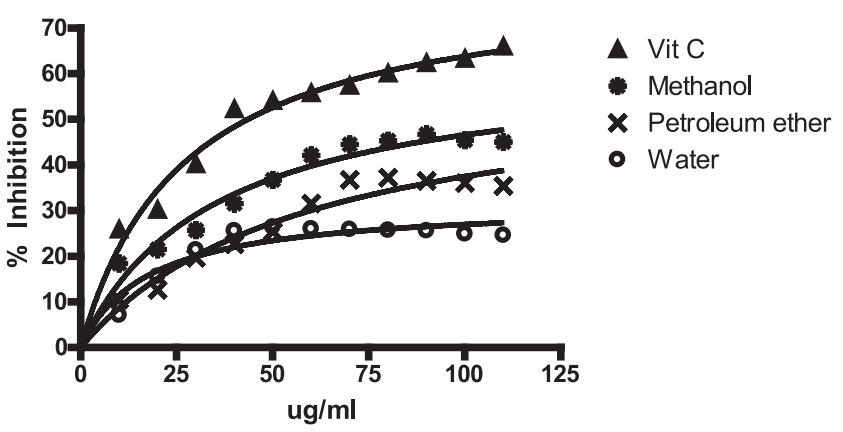

Figure 2b. Inhibition of Hydroxyl radical by $G$. penducalata.

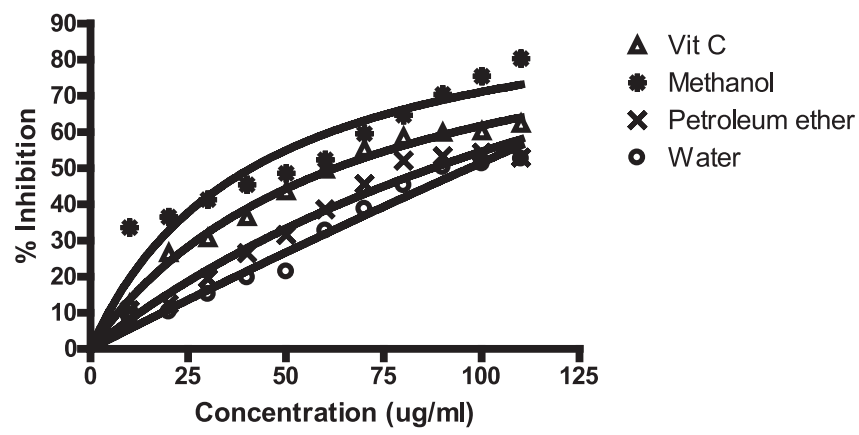

Figure 3a. Inhibition of. Free Oxygen radical by $D$. indica.

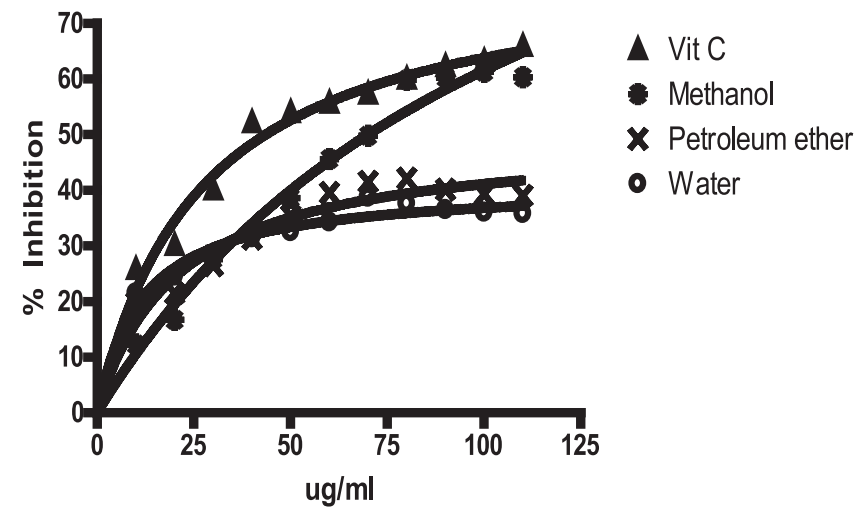

Figure 3b. Inhibition of Free Oxygen radical by G. penducalata.

of the methanolic extract of G. penduculata were 66.06 while that of the petroleum ether and water extract was $\mathrm{t}>110 \mathrm{ug} / \mathrm{ml}$ (Figure 3b).

Nitric oxide

The $\mathrm{IC}_{50}$ values of the scavenging activity of nitric oxide radicals for vit $\mathrm{C}$, methanol, petroleum ether and water extracts of $D$. indica were $41.82 \mathrm{ug} / \mathrm{ml}$, $39.73 \mathrm{ug} / \mathrm{ml}, 47.37 \mathrm{ug} / \mathrm{ml}$ and $71.87 \mathrm{ug} / \mathrm{ml}$, respectively (Figure 4a). On the other hand, the $\mathrm{IC}_{50}$ values for nitric oxide free radical scavenging activity of the methanolic and petroleum ether extracts of 
Munmee Das, et al.: In vitro anti oxidant activity and total phenolic content

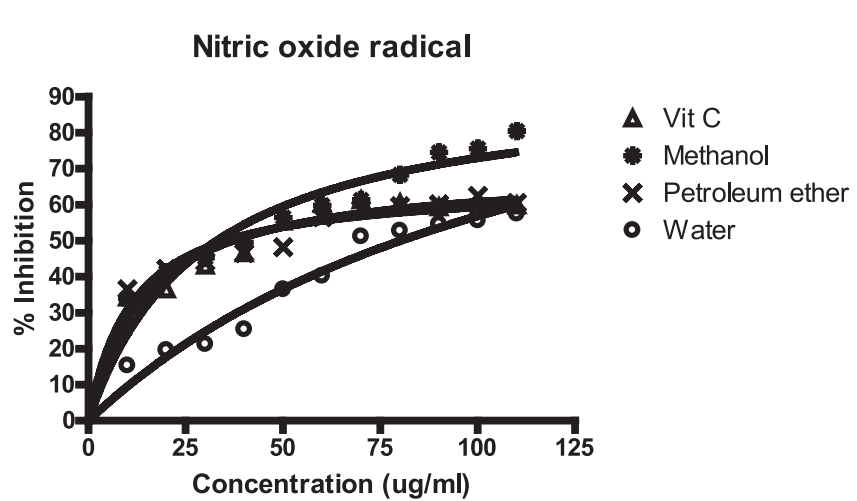

Figure 4a. Inhibition of Nitric oxide radical by D. indica.

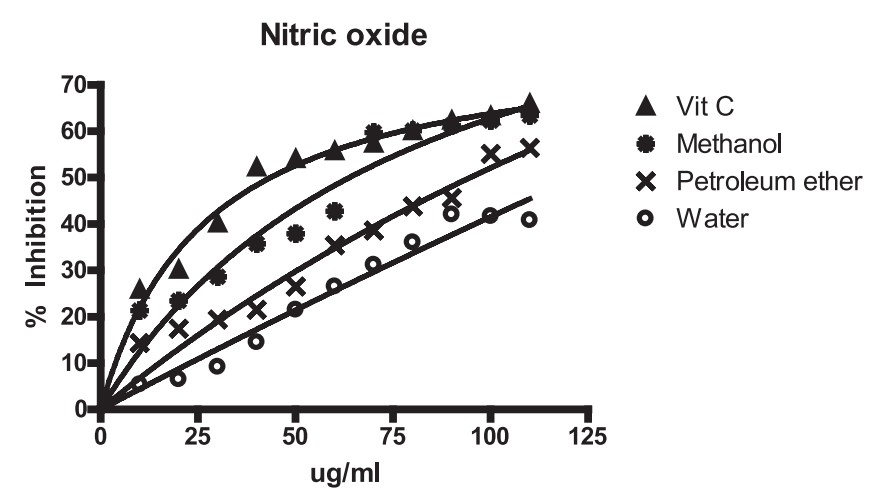

Figure 4b. Inhibition of Nitric radical by G. penducalata.

G. penducalata were 63.02 and $95.5 \mathrm{ug} / \mathrm{ml}$, respectively, while that of the water extract was $>110 \mathrm{ug} / \mathrm{ml}$ concentration (Figure 4b).

Reducting ability

The $\mathrm{IC}_{50}$ values for the reducing ability of vit $\mathrm{C}$, methanol, petroleum ether and water extracts of $D$. indica were $47.17 \mathrm{ug} / \mathrm{ml}, 40.18 \mathrm{ug} / \mathrm{ml}, 65.52 \mathrm{ug} / \mathrm{ml}$ and $102.45 \mathrm{ug} / \mathrm{ml}$, respectively (Figure 5a) while $\mathrm{IC}_{50}$ value for the extracts of G. penduculata was $>110 \mathrm{ug} / \mathrm{ml}$ (Figure 5b).

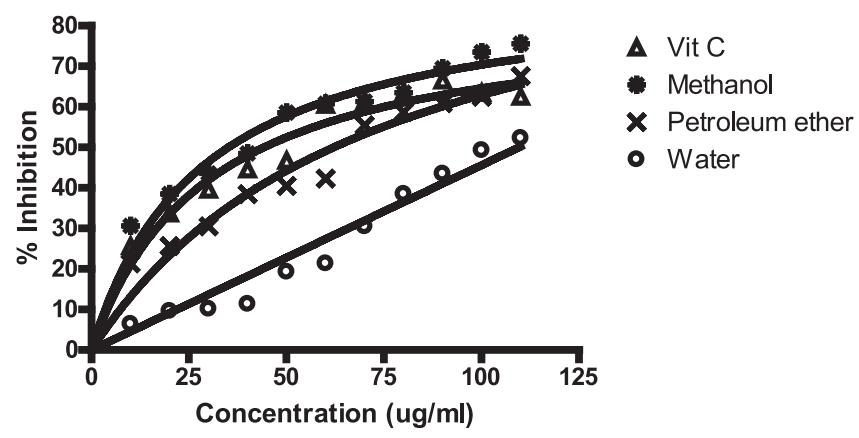

Figure 5a. Reductive ability of $D$. indica.

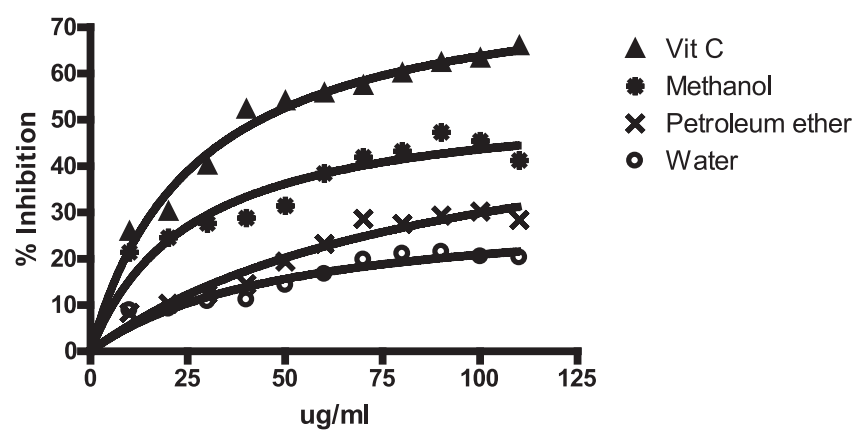

Figure 5b. Reductive ability of $G$. penducalata.

Phenolic content

The phenolic content of the methanolic, petroleum ether and water extracts of $D$. indica was $8 \%, 3 \%$ and $0.8 \%$, respectively while it was $5 \%, 1 \%$ and $0.6 \%$ for the respective extracts of $G$. penduculata.

\section{Ascorbic acid content}

The percentage of ascorbic acid estimated in the methanolic, petroleum ether and water extracts of the fruits of $D$. indica was $3 \%, 0.5 \%$ and $8 \%$, respectively while those of the fruits of G. penduculata were $1 \%, 0.2 \%$ and $6 \%$, respectively.

\section{DISCUSSION}

Free radicals are produced at very high levels during illness that damage human tissues. Right dietary sources can provide the much needed antioxidants to control the free radicals from damaging the affected tissues. ${ }^{[28]}$ During oxidative phosphorylation in mitochondria, hydrogen peroxide which is formed from super oxide anions by super oxide dismutase is detoxified to molecular oxygen and water by catalase.

Although the hydroxyl radical scavenging activity of the various extracts of $D$. indica exhibited $\mathrm{IC}_{50}$ values $<110 \mathrm{ug} /$ mlconcentration, the scavengingactivity of the extracts of G. penducalata was surprisingly $>110 \mathrm{ug} / \mathrm{ml}$.

Similarly the oxygen free radical scavenging activity of the different extracts of $D$. indica exhibited an $\mathrm{IC}_{50}$ value of $<110 \mathrm{ug} / \mathrm{ml}$ but the methanolic extract of the same exhibited a better free radical scavenging activity compared to that of vitamin C. Clearly, the methanolic extract of $D$. indica exhibited an $\mathrm{IC}_{50}$ value better than that of vitamin $\mathrm{C}$.

Nitric oxide (NO) is found in abundance in the nervous ${ }^{[29]}$ and muscular system. ${ }^{[30]}$ Excess of NO can cause tissue injury 


\section{Munmee Das, et al.: In vitro anti oxidant activity and total phenolic content}

leading to neuronal and muscular diseases like Parkinson's disease, stroke, Huntington's disease, amyotrophic lateral sclerosis and Duchenne muscular dystrophy. ${ }^{[31,32]}$ Production of high amount of NO in the large cerebral blood vessels leads to vasoconstriction and migraine ${ }^{[33,34]}$ along with erectile dysfunction which is one of the major complications of diabetes. ${ }^{[35]} \mathrm{NO}$ can inhibit glycolysis by competing with oxygen at cytochrome oxidase and cis acotinase. ${ }^{[36]}$

NO can react with superoxide to produce peroxynitrite which is neurotoxic. These peroxynitrites formed can also react with superoxide dismutase leading to nitration of tyrosine residues in skeletal muscles thereby causing muscle toxicity. ${ }^{[37]}$

The $\mathrm{IC}_{50}$ value for the nitric oxide scavenging activity of the methanolic extract of $D$. indica was lesser than that of vitamin $C$ which was used as a standard reference. Even though the $\mathrm{IC}_{50}$ values of petroleum ether and water extracts of $D$. indica was higher than that of vitamin $C$, these values were lesser than that of the similar solvent extracts obtained from the fruits of $G$. penducalata.

The DPPH scavenging activities of the various extracts of $D$. indica and $G$. penducalata were $<110 \mathrm{ug} / \mathrm{ml}$ but the methanolic extract of $D$. indica exhibited an $\mathrm{IC}_{50}$ value better than that of vitaminc $\mathrm{C}$.

Similarly the reducing ability of the methanolic extract of $D$. indica was found to be better than that of vitamin C. The concentration at which various extracts of $D$. indica exhibited its reductive property to be $<110 \mathrm{ug} / \mathrm{ml}$ whereas the same for $G$. penducalata was $>110 \mathrm{ug} / \mathrm{ml}$ concentration.

The phenolic content was found maximum in the methanolic extracts of both the plants. But the phenolic content of the methanolic extract of $D$. indica was the highest amongst all the extracts obtained from the fruits of D. indica and G. penducalata. Ascorbic acid being polar was maximum in the water extracts of both the plants. The phenolic and ascorbic acid contents of the petroleum ether extracts of both the plants was found to be intermediary between the methanolic and water extracts.

Polyphenols and vitamin $\mathrm{C}$ are important diet-derived antioxidants that provide enormous antioxidants to protect the body tissues against free radicals. ${ }^{[38-41]}$ These antioxidants react with the highly reactive ROS thereby preventing a chain reaction which formins highly reactive products resulting in lipid peroxidation. ${ }^{[42]}$

Therefore the higher amounts of phenolic content in the methanolic extract of $D$. indica might be one of the major causes for its enhanced in vitro antioxidant activity. Although the considerable level of ascorbic acid in the water extracts of the plants could not match the in vitro free radical scavenging activity of vitamin $\mathrm{C}$, the high levels of phenols in the methanolic extracts exhibited better free radical-scavenging activity compared to the ascorbic acid level of water extracts.

Traditionally $D$. Indica is used against stomach ache, ${ }^{[43]}$ fever, dysentery and constipation ${ }^{[4,45]}$. And it possess antidiabetic, hypolipidemic, ${ }^{[46]}$ hepatoprotective, anti-inflammatory, antileukemic and antimicrobial properties. ${ }^{[4]}$. These diseases can harm the living tissues and the antioxidant property of D. indica can protect the tissues against free radical damage initiated during the diseased state.

Vitamin C is a strong antioxidant but naturally eliminated from the body by renal excretion.

The decoctions of the fruits of both the plants are used in the Assamese cuisine. Even though the water extracts of both the plants exhibited $\mathrm{IC}_{50}$ values at higher concentrations, data obtained from our study affirms that the decoction of $D$. indica would be an ideal source of antioxidants to prevent the harmful activities of the free radicals generated in our body. Therefore the traditional food habits are potential sources of antioxidants to combat the deleterious effects produced by modern life-style diseases.

\section{CONCLUSION}

The present study concludes that Dillenia indica and Garcinia penducalata both possesses anti oxidant activities. The anti oxidant activity of Dillenia indica is superior to that of Garcinia penducalata due to its higher phenolic content.

\section{REFERENCES}

1. Halliwell B., Gutteridge JM. Free radicals in biology and medicine 2nd ed., Oxford: Clarendon Press.1989.

2. Desai KM, Chang T, Wang H, Ali B, Dhar A, Liu J, et al. Oxidative stress and aging: is methylglyoxal the hidden enemy? Canadian Journal of Physiology and Pharmacology. 2010; 88(3):273-84.

3. Tappia PS, Asemu G, Rodriguez-Leyva D. Phospholipase $C$ as a potential target for cardioprotection during oxidative stress. Canadian Journal of Physiology and Pharmacology. 2010; 88(3):249-63.

4. Khullar M, Al-Shudiefat AAS, Ludke A, Binepal G, Singal PK. Oxidative stress: a key contributor to diabetic cardiomyopathy. Canadian Journal of Physiology and Pharmacology. 2010; 88(3):233-40.

5. Provost C, Choufani F, Avedanian L, Bkaily G, Gobeil F, Jacques D. Nitric oxide and reactive oxygen species in the nucleus revisited. Canadian Journal of Physiology and Pharmacology. 2010; 88(3):296-304.

6. Tang D, Kang R, Zeh HJ, Lotze MT. High-Mobility Group Box 1, Oxidative Stress, and Disease Antioxidants \& Redox Signaling. 2011; 14(7):1315-35. 


\section{Munmee Das, et al.: In vitro anti oxidant activity and total phenolic content}

7. Cortina-Puig M, Prieto-Simón $\mathrm{B}$, Campàs $\mathrm{M}$, Calas-Blanchard $\mathrm{C}$, Marty JL. Determination of the antioxidants' ability to scavenge free radicals using biosensors. Advances in Experimental Medicine and Biology. 2010; 698:222-33

8. Obrenovich ME, Nair NG, Beyaz A, Aliev G, Reddy VP. The role of polyphenolic antioxidants in health, disease, and aging. Rejuvenation Research. 2010; 13(6): 631-43.

9. Perron NR, Brumaghim JL. A review of the antioxidant mechanisms of polyphenol compounds related to iron binding. Cell Biochemistry and Biophysics. 2009; 53(2):75-100.

10. Ranilla LG, Kwon Y, Apostolidis E, Shetty K. Phenolic compounds, antioxidant activity and in vitro inhibitory potential against key enzymes relevant for hyperglycemia and hypertension of commonly used medicinal plants, herbs and spices in Latin America. Bioresource Technology. 2010; 101(12):4676-89.

11. Eaton SB, Konner M, Shostak M. Stone agers in the fast lane: chronic degenerative diseases in evolutionary perspective. Am. J. Med. 1988; 84:739-49.

12. Milton K. Nutritional characteristics of wild primate foods: do the diets of our closest living relatives have lessons for us? Nutrition 15; 1999:488-98.

13. Tuppen HAL, Blakely EL, Turnbull DM, Taylor RW. Mitochondrial DNA mutations and human disease. Biochimica et Biophysica Acta (BBA) Bioenergetics. 2010; 1797(2):113-28.

14. Wallace DC. Mitochondrial DNA mutations in disease and aging. Environmental and Molecular Mutagenesis. 2010; 51:440-50.

15. Rabø| R, Boushel R, Dela F. Mitochondrial oxidative function and type 2 diabetes. Applied Physiology, Nutrition, and Metabolism. 2006; 31(6):675-83.

16. Jaganath IB, Crozier A. Dietary Flavonoids and Phenolic Compounds, in Plant Phenolics and Human Health: Biochemistry, Nutrition, and Pharmacology (ed C. G. Fraga), John Wiley \& Sons, Inc., Hoboken, NJ, USA. 2009.

17. Choudhury MK, Venkatraman S, Upadhyay L. Analysis of in vitro anti oxidant potential of Streblus asper leaves water extract, Biomedicine. 2009; 29(3):263-7.

18. Gupta S, Prakash J. Studies on indian green leafy vegetables for their antioxidant activity. Plant Foods for Human Nutrition (Formerly Qualitas Plantarum). 2009; 64(1):39-45.

19. Kumar BD, Mitra A, Manjunatha A. In vitro and in vivo studies of antidiabetic Indian medicinal plant; A review. Journal of Herbal Medicine and Toxicology. 2009; 3(2):9-14.

20. Cotelle A, Bernier JL, Catleau JP, Pommery J, Wallet JC, Gaydou EM. Antioxidant properties of hydroxyl flavones. Free radic Biol Med. 1996; 20(1):35-43.

21. Marcocci L, Magyuire JJ, Droy-lefaix MT, Packerl. The nitric oxide scavenging properties of gingko biloba extract EGB 761. Biochem. Biophys. Res. Commun. 1994; 201(2):748-55.

22. Kunchandy E, Rao MNA. Oxygen radical scavenging activity of curcuminoid. International Journal of Pharmacognosy. 1990; 58;237-40.

23. Ohkawa M, Oshiki N, Yagi K. Assay for lipid peroxides in animal tissues by thiobarbituric acid reaction. Anal Biochem. 1979; 95:351-8.

24. Robak J, Gryglewski RJ. Flavonoids are scavengers of superoxide anions. Biochem Pharmacol. 1988; 37(5):837-41.

25. Jayprakash GK, Singh RP, Sakariah KK. Anti oxidant activities of grape seed extracts on peroxidation models in vitro. J Agri Food Chem. 2001; 73(3):285-90

26. Slinkard K, Singleton VL. Total phenol analysis: automation and comparison with manual methods. Am. J. Enol. Viticul. 1997; 28:49-55.
27. Indian Pharmacopia Government of India, Ministry of Health and Family Welfare, The Controller of Publications, Delhi. Vol. 1. 1996.

28. Choudhury MK, Venkatraman S, Upadhyay L. Antioxidant and Hypoglycemic Property of Streblus asper in Streptozotocin induced diabetic rats. Journal of Phamacy Research. 2011; 4:1958-61.

29. Bredt DS, Snyder SH. Nitric oxide mediates glutamatelinked enhancement of cGMP levels in the cerebellum. Proc. Natl. Acad. Sci. USA. 1989; 86:9030-33.

30. Kobzik L, Reid MB, Bredt DS, Stamler JS. Nitric oxide in skeletal muscle. Nature. 1994; 372:546-8

31. Samdani AF, Dawson TM, Dawson VL. Nitric oxide synthase in models of focal ischemia. Stroke. 1997; 28:1283-8.

32. Brenman JE, Chao D, Xia SH, Aldape K, Bredt D. Nitric oxide synthase complexed with dystrophin and absent from skeletal muscle sarcolemma in Duchenne muscular dystrophy. Cell. 1995; 82:743-52.

33. Bredt DS, Hwang PM, Snyder SH. Localization of nitric oxide synthase indicating a neural role for nitric oxide. Nature. 1990; 347:768-70.

34. Welch KM. Drug therapy of migraine. N. Engl. J. Med. 1993; 329: 1476-83.

35. Vernet D, Cai L, Garban H, Babbitt ML, Murray FT, Rajfer J, GonzalezCadavid NF. Reduction of penile nitric oxide synthase in diabetic BB/ WORdp (type I) and BBZ/WORdp (type II) rats with erectile dysfunction. Endocrinology. 1995; 136:5709-17.

36. Christopherson KS, Bredt DS. Perspectives series: nitric oxide and nitric oxide synthases nitric oxide in excitable tissues: physiological roles and disease. J. Clin. Invest. 1997;100(10):2424-9.

37. Beckman JS, Koppenol WH. Nitric oxide, superoxide, and peroxynitrite: the good, the bad, and ugly. Am. J. Physiol. 1996; 271:C1424-37.

38. Mattila PH, Hellström J, McDougall G, Dobson G, Pihlava JM, Tiirikka T, et al. Polyphenol and vitamin $\mathrm{C}$ contents in European commercial blackcurrant juice products. Food Chemistry. 2011; 127(3):1216-23.

39. Visioli F, Lastra CA, Andres-Lacueva C, Aviram M, Calhau C, Cassano A, et al. Polyphenols and Human Health: A Prospectus. Food Science and Nutrition. 2011; 51(6):524-46.

40. Zhang J, Zhang X, Dhakall B, Gross MD, Kadlubar FF, Anderson KE. Sequence variants in antioxidant defense and DNA repair genes, dietary antioxidants, and pancreatic cancer risk. Int. J. Mol. Epidemiol. Genet. 2011; 2(3):236-44.

41. Micucci P, Alonso MR, Turner S, Davicino R, Anesini C. Antioxidant and antimicrobial activities of Larrea divaricata Cav. aqueous extract on vitamin c from natural orange juice. Food and Nutrition Sciences. 2; 2011:35-46.

42. Azzi A, Davies KJA, Kelly F. Free radical biology-terminology and critical thinking, FEBS Lett. 2004; 558:3-6.

43. Kala CK. Ethnomedicinal botany of the Apatani in the Eastern Himalayan region of India. Journal of Ethnobiology and Ethnomedicine. 2005; 1:1.

44. Pradhan BK, Badola HK. Ethnomedicinal plant use by Lepcha tribe of Dzongu valley, bordering Khangchendzonga Biosphere Reserve, in North Sikkim, India. Journal of Ethnobiology and Ethnomedicine. 2008; 4:1-22.

45. Sharma UK, Pegu S. Ethnobotany of religious and supernatural beliefs of the Mising tribes of Assam with special reference to the 'Dobur Uie'. Journal of Ethnobiology and Ethnomedicine. 2011; 7:1-16.

46. Kumar S, Kumar V, Prakash O. Anti diabetic and hypolipidemic activities of D. Indica extract in diabetic rats. J. Chin. Interr. Med. 2011; 9(5):570-4.

47. Padmavathi D, Netravati Deshpande SaralaA. Dillenia indica: a review on morphology, phytochemistry and pharmacological aspects. Research Journal of Pharmacy and Technology. 2011; 4(7):1037-9. 